\title{
EXPLORING ENVIRONMENTAL KUZNETS CURVE. AN INVESTIGATION ON EU ECONOMIES
}

\author{
Daniel BADULESCU ${ }^{(1)}{ }^{1}$, Alina BADULESCU (D)2*, Ramona SIMUT ${ }^{(1)}{ }^{3}$, \\ Dorin BACD ${ }^{4}$, Elena-Ana IANCU ${ }^{5}$, Nicolaie IANCU6 \\ 1,2,3,4 Department of Economics and Business, Faculty of Economic Sciences, \\ University of Oradea, Oradea, Romania \\ ${ }^{5}$ Doctoral School of Law, Alexandru Ioan Cuza Police Academy, Bucharest, Romania \\ ${ }^{6}$ Department of Social Sciences, Agora University, Oradea, Romania
}

Received 09 September 2018; accepted 30 June 2019

\begin{abstract}
Designing and implementing relevant and effective environmental policies and fostering green and environmental-friendly approaches and behaviors are constant aims for policy makers all over the world. Concurrently, implementing environmental policies involves significant economic and financial efforts, in order to repair environmental damage and to prevent future negative environmental consequences. How effective are the environmental expenditures and how are they related to the economic growth, i.e. the GDP level, are issues of major concern at a governmental level. In this article we are examining the relation between GDP and environmental expenditure, by using statistical data available for EU economies, for the time period 1995-2013. We found that the Environmental Kuznets Curve hypothesis is supported in most of the EU economies, both for government environmental protection and specialized providers, public and private environmental protection. Further and deeper analyses performed showed different situations for specific countries and even a negative relation between GDP and government environmental protection for specific cases.
\end{abstract}

Keywords: environmental expenditure, Kuznets curve, GDP growth, EU member states.

JEL Classification: O44, Q56, O13, Q58.

\section{Introduction}

Economic and social activities are responsible in different forms and intensities for the transformation and degradation of the environment. Moreover, in recent times, efforts to reduce the negative consequences of human development make sense insofar as they are systematic, global and long-term. This involves a concerted effort at all levels, starting with international and regional institutions and bodies, governments and public authorities, companies (espe-

*Corresponding author. E-mail: abadulescu@uoradea.ro

This is an Open Access article distributed under the terms of the Creative Commons Attribution License (http://creativecommons. org/licenses/by/4.0/), which permits unrestricted use, distribution, and reproduction in any medium, provided the original author and source are credited. 
cially those providing environmental services), non-governmental organizations, as well as individuals and households as consumers.

Local, national and international policies endorse environmental issues and sustainable development as strategic objectives, through various economic and fiscal means (European Commission, 2011, p. 6). In the last decades it has been noted that "environmental protection activities gradually shifted from collection and treatment of pollutants to policies of pollution prevention, to an increasing internalization of corporations' environmental protection activities" (Eurostat, 2017, p. 10), policies consistent with a more environmentally friendly society that prefers less polluting products or businesses (Bac, 2008; D. Badulescu, Bungau, \& A. Badulescu, 2015). This also means a gradual shift from administratively implemented policies, such as command and control measures, "towards the implementation of new market-based instruments" (De Santis \& Lasinio, 2015, p. 2) or even environmental measures taken on a voluntary basis.

According to Eurostat, "environmental protection expenditure consists of the economic resources devoted to all activities and actions which have as their main purpose the prevention, reduction and elimination of pollution and of any other degradation of the environment" (Eurostat, 2017, p. 10). However, there are many issues to be addressed, regarding the amount spent for environmental protection and their effects, the existence (or not) of a pattern of environmental spending for different groups of economies, with specific macroeconomic profiles etc., in order to design an effective environmental policy.

On a different hand, European countries are comparatively energy efficient and many economic policies are implemented to address the environmental-economic growth nexus. Our motivation to focus on European countries is related exactly to the diversity of environmental policies and their effects, which provides rich investigation opportunities. Moreover, the diversity of the European countries with regard to the different stages of economic development and environmental improvements, which are captured in reliable statistical data over long periods of time, is another motivation for our focus.

In this context, following our previous research (D. Badulescu, A. Badulescu, SiposGug, \& Rangone, 2016), we now examine the relationship between GDP and environmental spending, in several (i.e. 21) European countries during 1995-2013. Our main purpose is to investigate and bring new insights related to the shape of the environmental Kuznets curve (EKC) for certain (groups of) economies. Finally, we investigate further developments of this indicator. To do this, we will basically examine the following two hypotheses: (1) for EU member states, the correlation between environmental expenditure and GDP is positive and an EKC U-shape is confirmed empirically, and, respectively, (2) The EKC effect is negative and statistically significant for selected EU countries. More precisely, the environmental expenditure and GDP will increase up to a critical point and then the environmental expenditure will decrease due to a positive effect of GDP.

The paper is organized as follows: in the first part, after the Introduction, we review the relevant literature regarding the relationship between environmental expenditure and economic growth. In the second part we present the research methodology, including data sources, the indicators used and the research hypotheses, followed by results and discussion. Finally, we conclude and present policy recommendations. 


\section{Theoretical background}

Environmental degradation has usually been associated with economic growth, and research has theoretically and empirically attempted to understand and explain this issue. One of the most important but also controversial hypotheses (Panayotou, 2000; Everett, Ishwaran, Ansaloni, \& Rubin, 2010), is considered to be the Environmental Kuznets Curve (EKC), inspired by Simon Kuznets' works (1955), later resumed by Grossman and Krueger (1991). It promotes the hypothesis of an inverted U-shaped relationship between economic growth and pollution (or between economic output per capita and environment protection). In other words, along with the economic development, the quality of the environment deteriorates in a first phase, but it gradually improves with economic development, or due to increased society's demand for a cleaner environment as GDP per capita increases. With all the clarity of this argumentation, most researchers considered that EKC is an empirical phenomenon that needs to be discussed or confirmed by solid theoretical models and global analyses of structural trends, rather than finding suitable circumstances. The society's interest for environmental issues is strongly related with a significant increase in income and economic development, and the propensity for environmental improvement instead of increasing consumption along with economic growth. This seems to be one of the arguments of the measures stating that the priority of developing countries should be economic growth, but not the implementation of restrictive environmental measures. Specifically, it is considered that, as these countries will increase their living standards (GDP / capita), they can reverse the trend and compensate for the damage of the economic growth with repairable environmental investments, "the best - and probably only - way to attain a decent environment in most countries is to become rich" (Beckerman, 1992).

An increase in pollution levels is the result of productive activities and technological improvements (Lopez, 1994) or consumption (John \& Pecchenino, 1994), and only economies of scale (Andreoni \& Levinson, 2001) or a full satisfaction of consumption (satiation) (Lieb, 2002) may reduce this level and a better fit to the EKC profile. In other words, the accumulation of a consistent stock capital could ensure the substitution (or decrease) of polluting technologies or products and their effects (Selden \& Song, 1994; Dinda, 2005). Complementary perspectives come from Tahvonen and Kuuluvainen (1993, p. 101), asserting a "the smooth substitution between emissions and capital" (the substitutions of human capital and natural capital) that ensures sustainable long-term growth, or Dinda (2005), who states that restoration of environmental quality is possible only when economy accumulates enough capital stocks. "The shift from insufficient to sufficient investment for upgrading environment is the basis for curve down the pollution level, and thus, correspondingly forms the inverted Ushaped relationship between pollution and economic growth" (Dinda, 2005, p. 410).

An essential element of EKC hypothesis is the existence of turning points, hence, a considerable practical interest to determine their values, usually in relation with air and water quality, waste accumulation, energy consumption and population density.

Selden and Song (1994), analyzing various pollutants and $\mathrm{NO}_{\mathrm{x}} \mathrm{s}$, confirmed the existence of the EKC and assumed the hypothesis of a turning point (or the point beyond which GDP per capita growth starts to lead to a reduction of emissions) of about USD 10.000 (in 
1985 constant prices), while Grossman and Krueger, also confirming the formation of the EKC for almost all environmental indicators, indicated a smaller turning point, initially at 4-5.000 USD (Grossman \& Krueger, 1991), and subsequently increased to around USD 8.000 (in 1985 constant prices) (Grossman \& Krueger, 1995). Other studies, introducing into the analysis of EKC curve a larger set of environmental variables, estimated a higher turning point. It has been found that it differs according to the analyzed variables (pollutant) and the chosen countries' sample, from around USD 6.000 to USD 18.000 (Cropper \& Griffiths, 1994; Galeotti \& Lanza, 1999), and even more (around USD 50.000 USD) if global pollutants are being analyzed (Cole, 2003). Dijkgraaf and Vollebergh (2005) reported a turning point of USD 20.600 (in 1990 constant prices) and found there is no unique EKC for each country. Galeotti, Lanza, and Pauli (2006) claim a turning point ranging from USD 15.500 to USD 16.600 for the OECD countries' sample, and between USD 15.600 and USD 21.200 for the non-OECD sample.

However, the analysis of global pollutants, such as $\mathrm{CO}_{2}$, indicates not only turning points of over USD 20,000 (much higher than other "local" pollutants), but also a lack of consensus even about the formation and existence of EKCs (Uchiyama, 2016). Recent papers, for example Dutt (2009) or Everett et al. (2010), approximate a turning point of ca. USD 34,000 per capita. Confirming this level would lead to the observation that no more than $10 \%$ of developed economies have overcome this level, while a majority of developed countries will still be on the upward slope of pollution for another 2 or 3 decades. Obviously, the scenarios for developing economies are even more worrying.

Suri and Chapman (1998), Cole (2004) or Kearsley and Riddel (2010) link the EKC model with international trade. On one hand, there are the measures taken by developing countries to increase their exports, including export goods made by polluting industries. On the other hand, we refer to developed countries that import goods (made with polluting technologies), when internal regulations restrict their domestic production, or firms' strategies from rich countries that voluntarily choose to re-locate production and technology facilities to poor countries, with permissive legislation - the so-called "pollution haven hypothesis" ( $\mathrm{PHH})$ (Dinda, 2005), or the "industrial displacement effect of "dirty" industries" (Hettige, Lucas, \& Wheeler, 1992).

Briefly, the upward slope of the EKC curve is given by exports of goods (to developed countries) and the downward trend in the imports of goods (from developing countries). A similar explanation resides in the hypothesis of countries' propensity "as they get richer to spin-off pollution-intensive products to lower-income countries with lower environmental standards" (Panayotou, 2000). More precisely, when approaching the relationship between income and environment, several authors assign the pollution haven hypothesis with the level and structure of consumption, rather than production. Thus, when consumption patterns are not the same as the production structure, environmental movements from one country to another will occur, but eventually the negative consequences of this process are born by the less developed countries (Ekins, 1997).

Not all scholars agree with the PPH theory: they either disagree with its construction as such (Cole, 2004), or they are skeptical regarding the correspondences between the two categories of economies as pollution sources, i.e. the reduction of pollutant emissions in 
developed countries is slower than their increase in developing countries (Peters, Minx, Weber, \& Edenhofer, 2011; Levinson \& Taylor, 2004). In other cases, they simply affirm the inconsistency of PHH associated policies (Grossman \& Krueger, 1995) or the necessity "to build a new/alternative Green GDP indicator that should give us a clearer perspective of the consequences of economic progress by offering a new approach in quantifying the cost of ecological and environmental degradation" (Stjepanović, Tomić, \& Škare, 2017, p. 574).

There are researchers considering that limiting economic development is not a solution, but, on the contrary, only economic growth can support the expenditures related to environmental protection, or "if the EKC hypothesis held generally, it could imply that instead of being a threat to the environment [...] economic growth is the means to environmental improvement" (Stern, Common, \& Barbier, 1996, p. 1152).

However, there are opinions questioning the relevance of EKC hypothesis, considering that as long as there is evidence that EKC relationship works only for certain economies and for certain local pollutants, it cannot be generalized. Consequently, there is a limited applicability of the EKC as a predictor of environmental performance or a signal of convergence, as countries are developing (Everet et al., 2010; Magnani, 2000).

Alternative theories, such as the limits to growth theory, approach the economy-environment relationship in terms of environmental damage. Although the debate on the limits to growth does not stir the same interest as it did nearly five decades ago (i.e. the well-known Report for the Club of Rome's - The Limits to Growth) (D. Meadows, D. Meadows, Randers, \& Behrens, 1972), it remains a milestone through the analysis of the evolution of the three essential factors of the relationship between human development and the environment: the rate of technological progress; future changes in the composition of output, and the possibilities of substitution (Lecomber, 1975; Ekins, 1993).

Thus, it foreshadows the contradiction between the optimistic approach, which supports the power of inventions and the technological progress that can solve any problem, and the pessimistic approach - the success of technological solutions can generate new problems and may complicate the challenges of the future. Moreover, Stern (2004) considers that, although the existing pollutants' emissions are diminishing, the continuing economic growth generates new and more dangerous pollutants to appear. He discusses a possible continuing relationship between economic growth and the environment degradation in the context of international competition, known as the "race to the bottom" (World Trade Organization [WTO], 1999). It is based on the assumption that decision makers - concerned by the competition from aboard, international trade trends and the specific investments - will press for relaxation of environmental standards, and will thus damage the environment across the global system (Frankel, 2003, p. 12). International competition would primarily determine increased environmental damage, up to the point when developed countries appreciate the environmental damage caused and decide to diminish their environmental impact. Unfortunately, this apparent decrease will not be realized strictly by improving green technology, but also by "outsourcing" pollution in poorer countries.

Other major topics, both in research and policy, are the influence and the effects of environmental expenditure and regulation on economic development (Pearce \& Palmer, 2001; Dechezleprêtre \& Sato, 2014; Koźluk \& Zipperer, 2015), if command and control measures 
limit technological progress, as they do not offer any motivation for innovation (De Santis \& Lasinio, 2015), reduce productivity growth (Smith \& Sims, 1985; Managi, Opaluch, Jin, \& Grigalunas, 2005) and firms' profitability with respect to the relationship between free trade and pollution regulations (Alpay, Buccola, \& Kerkvliet, 2002). The negative effects on labor productivity are either ambiguous (Becker, 2011), or contradictory, depending on the timeframe (Alpay et al., 2002), on the analysis model (Gray, 1987), or the chosen pollutant (Greenstone, List, \& Syverson, 2012).

There is also the opinion that, rather than displaying a negative impact on economic growth, environmental policy could lead to competitiveness, as "restrictive environmental policies had a growth-promoting effect, in particular, on productivity growth via their influence on ICT capital accumulation" (De Santis \& Lasinio, 2015, p. 19; Yang, Tseng, \& Chen, 2012; Wu \& Wang, 2008; Yörük \& Zaim, 2005), inspiring new power generation technologies with zero emissions (Rogalev, Komarov, Kindra, \& Zlyvko, 2018). This “win-win” approach, otherwise criticized for its excessive theoretical approach and the free-lunch argument, is mainly associated with the contributions of Michael Porter (1998), or Porter and van der Linde (1995), who have suggested that "well-designed environmental policies might actually enhance productivity and increase innovation, yielding direct economic benefits next to the environmental benefits" (Koźluk \& Zipperer, 2015, p. 156). Environmental policy could determine countries "to establish new projects and implement green technologies that promote renewable energy and energy efficiency" (Al-Mulali, Ozturk, \& Solarin, 2016, p. 281), as a way to slow down the environmental degradation by CO2 emissions (Anastacio, 2017, p. 70), both in developed and in developing countries (Shahbaz, Dube, Ozturk, \& Jalil, 2015; L. M. Marques, Fuinhas, \& A. C. Marques, 2017). Moreover, an intelligent environmental policy, based on increasing international commercial exchanges or large international cooperation (as mega projects of Belt and Road Initiative, triggering implicitly economic growth), could help in alleviating negative effects of pollution and global warming (Jebli, Youssef, \& Ozturk, 2016; Rauf et al., 2018). Other researchers link this perspective to the circular economy, with a better management and accounting of natural resources, industrial processes, renewable energy or recycling (Rafindadi \& Ozturk, 2017; Mishenin, Koblianska, Medvid, \& Maistrenko, 2018), all having direct and positive effects on the economy, companies or communities (Vegera, Malei, Sapeha, \& Sushko, 2018a; Vegera, Malei, \& Trubovich, 2018b).

\section{Research methodology}

There is a large number of empirical studies testing the EKC hypothesis starting from different methods, datasets, and variables. Studies investigating the relationship between the environment and economic growth have started since 1990 as a reaction to environmental problems. The most commonly used methods in analyzing the environment and economic growth nexus are the panel data econometric methods (Dijkgraaf \& Vollebergh, 2005; AlMulali, Ozturk, \& Lean, 2015; Al-Mulali et al., 2016; Jebli et al., 2016; Acaravci \& Akalin, 2017; Anastacio, 2017). These models have become popular among researchers due to the ability to function well with short time series, and thus increasing the degree of freedom and being also more capable of controlling the issue of heterogeneity and serial correlation 
compared to time series data and cross-section data. The cointegration method is also used in the study of the EKC hypothesis. A more recent cointegration method used in the literature was introduced by Pesaran and Shin (1999) and further extended by Pesaran, Shin, and Smith (2001), i.e. the so-called autoregressive distributed lag (ARDL) model. Several studies have analyzed the EKC hypothesis using the autoregressive distributed lag (ARDL) bounds testing approach of cointegration for different countries or regions (i.e. for nineteen European countries: Acaravci \& Ozturk (2010); Portugal: Shahbaz et al. (2015), six African Countries: Mensah (2014); Germany: Rafindadi \& Ozturk (2017); four regions, namely America, Europe and Central Asia, Asia Pacific, Africa and the Middle East: Marques et al. (2017)). An interesting econometric analysis is proposed by Keho (2017): the use of quantile regression to reexamine the effect of economic growth and energy consumption on carbon dioxide $\left(\mathrm{CO}_{2}\right)$ emissions for five panels of 59 countries.

Following this context, the aim of this study is to analyze the relationship between environmental expenditure and GDP for the EU countries for the period 1995-2013, by using a panel data analysis and a regression equation for an individual analysis on the European Union selected countries. The data were retrieved from Eurostat and are measured in euro/ capita.

In comprehensive terms, Eurostat defined environmental protection expenditure as "the money spent on all the activities and actions that are aimed at the prevention, reduction and elimination of pollution as well as any other degradation of the environment, resulting from the production processes or the consumption of goods and services" (European Commission, 2011, p. 8). Thus, environmental expenditure is analyzed by three main actors in environmental spending, i.e. the public sector, the public and private specialized producers (public and private enterprises specialized in environmental services such as waste collection) and the industry (European Commission, 2011, p. 19). Recently, European Union highlights environmental protection expenditure accounts (EPEA) in line with its own regulations and with the international United Nations System of National Accounts. Hence, EPEA "measure the economic resources devoted to all activities and actions which have as their main purpose the prevention, reduction and elimination of pollution and of any other degradation of the environment" (Eurostat, 2017, p. 3). Their role is to highlight more precisely the financial commitment of an economy to environmental protection, the influence of environmental protection costs on the international competitiveness, the implementation of the "polluter pays" principle and the effectiveness of environmental control mechanisms.

Starting from these variables, i.e. environmental expenditure and GDP, we have stated and tested the following hypotheses:

H1: For the whole EU area, the correlation between environmental expenditure and GDP is positive and an EKC U-shape is confirmed empirically;

H2: The EKC effect is negative and statistically significant across the selected EU countries: the environmental expenditure and GDP will increase up to a critical point, and then the environmental expenditure will decrease due to a positive effect of GDP.

In this article, we consider the independent variable as measured by Gross domestic product (GDP), which is, according to Eurostat (2017), the most frequently used measure for the overall size of an economy. 
As measures of environmental protection activities we used indicators reported by Eurostat.

According to Environmental Protection Expenditure Accounts Handbook (Eurostat, 2017, p. 154) and NACE Rev.2 (Eurostat, 2008) the NACE codes (positions) of specific environmental protection activities, other than ancillary activities, are the following: Section E - Water Supply; Sewerage, Waste Management and Remediation Activities, thus: Division 37 Sewerage (all), Division 38 Waste collection, treatment and disposal activities; materials recovery namely, Group 38.1 Waste collection and, respective, 38.2 Waste treatment and disposal; Division 39 Remediation activities and other waste management services (all), and waste water treatment as secondary activities comprised in Division 36 Water collection, treatment and supply. Moreover, we find environmental protection activities in: Section A Agriculture, Forestry and Fishing, in Section F - Construction, in Section M - Professional, Scientific and Technical Activities - technical testing and analysis, other professional, scientific and technical activities class n.e.c. (not elsewhere classified), in Section N - Administrative and Support Service, in Section O - Public Administration and Defense; Compulsory Social Security, even if environmental protection activities are not included in distinctive classes.

Regarding the sample, due to insufficient data available for several countries (a list is presented for each analysis), we could not include in the analysis all $28 \mathrm{EU}$ member states. Consequently, the final sample included 21 countries for Environmental protection expenditure by central government and 17 countries for Environmental protection expenditure by private and public specialized producers of environmental protection services.

Data analysis was performed by using Eviews 9, after data was collected from the Eurostat database, and underwent preliminary preparation and formatting. In the first part of the paper we present the results of a panel regression, and in the second part of the paper the results of individual analyses carried on selected EU countries.

A generally accepted functional model for testing the two hypotheses is estimation of a standard polynomial relationship between environmental expenditure and GDP. Since the estimation methodology applied in our analysis incorporates also a panel data, we will use in the first part of the analysis the following model (logs on both sides of the equation for a more meaningful interpretation in terms of the rate of change):

$$
\operatorname{Ln}(E n v)=\alpha_{i}+\beta_{1} \ln (G D P)_{i t}+\beta_{2} \ln (G D P)_{i t}^{2}+\gamma t+\varepsilon_{i t},
$$

where Env is the environmental protection expenditure indicator (measured in euro/inhabitant) and GDP is the Gross Domestic Product per capita (measured in euro/inhabitant), ln indicates natural logarithms, $\alpha$ and $\gamma$ are intercept parameters that vary depending on countries $(i)$ and years $(t), \beta$ is the coefficient of the explanatory variables and $\varepsilon$ it is an error term. The main purpose for including the squared GDP in the model is to support the hypothesis of an inverted $U$ relationship between the GDP growth and the environmental protection expenditure.

In the literature, either the fixed or random effect are used to estimate a panel data model. The fixed effect model is used if the individual specific component is not independent with respect to the exogenous variables or it is assumed that the countries are very different. If 
the individual specific component is assumed to be random with respect to the exogenous variables, the random effect model is employed (Dewan \& Hussein, 2001, p. 27). To examine these two models, the F-test will be used in the case of the fixed effect model, while for the random effect model the Wald test will be used.

To establish which of the models is more appropriate, we will use the Hausman test (Hausman, 1978). According to the Hausman test, if a null hypothesis that individual effects are uncorrelated with other regressors in the model is not rejected, a fixed effect model will not be a consistent estimator. In such circumstances, a random effect model is our preferable estimator.

\section{Results and discussion}

The relationship between Environmental Protection Expenditure and GDP for the selected EU countries by using the panel regression model is presented in the next two tables, based on data provided by European Commission (2011) and Eurostat (2015).

Table 1 shows the regression results of the fixed effect and Table 2 shows the regression results of the random effect models for the period 1995-2013 for selected EU countries. The final sample included 21 countries when the dependent variable is represented by logarithm of Environmental protection expenditure by central government, and 17 countries when the dependent variable is represented by logarithm of Environmental protection expenditure by private and public specialized producers of environmental protection services.

The probability value related to the F-test for the fixed-effect models and the Wald statistics for the random effect models is significant, namely 0.00 in all four cases. This means that none of the coefficients of our models is equal to zero.

Based on the outcomes of the models presented in Table 1 and Table 2, we can accept the existence of an inverted $U$ relationship (concave curvature), since the probability value associate to the coefficient of the GDP quadratic term is negative and significant at $90 \%$ significance level. Therefore, we can conclude that both Central Government Environmental Protection Expenditure and Environmental protection expenditure by specialized providers (public and private) has the tendency to initially increase and then decrease over time. The results show also a negative linear time effect in the case of the Central Government Environmental Protection Expenditure and a positive time effect in Environmental protection expenditure by specialized providers (public and private) case. We can conclude that, based on the annual data over the period 1995-2013, the Central Government Environmental Protection Expenditure has been decreasing linearly with respect to the growth in the level of GDP, while Environmental protection expenditure by specialized providers (public and private) tends to increase yearly with respect to the growth in the level of GDP.

To decide which model is more appropriate, i.e. fixed effect or random effect, we used the Hausman test. In both cases, we cannot reject the null hypothesis stating that a random effect model is better than a fixed one, because the Chi-Sq. Statistic (3) for Central Government Environmental Protection Expenditure is equal with 6.17 and the Prob. $>$ Chi-Sq. $=0.1034$, while for Environmental protection expenditure by specialized providers (public and private) the Chi-Sq. Statistic (3) is 3.957914 and the Prob. > Chi-Sq. 0.2660. Thus, the random effect model is our preferred model for the analysis. 
Table 1. Fixed effect regression Environmental protection and GDP in the European Union countries

\begin{tabular}{|c|c|c|c|c|c|}
\hline \multicolumn{6}{|c|}{ Dependent variable: logarithm of Environmental protection expenditure by central government } \\
\hline \multirow[b]{2}{*}{ Variable } & \multicolumn{5}{|c|}{$\begin{array}{l}\text { Number of observations 399; Sample period 1995-2013; } \\
\text { Number of time periods }(\mathrm{T})=19 \text {; Number of countries }(\mathrm{N})=21\end{array}$} \\
\hline & Coeff. & Std. error & t-statistic & Prob & F-test (prob.) \\
\hline Intercept & -17.04555 & 3.510465 & -4.855640 & 0.0000 & \multirow{4}{*}{$\begin{array}{l}128.5692 \\
(0.0000)\end{array}$} \\
\hline GDP per capita $(\log )$ & 2.806883 & 0.895278 & 3.135210 & 0.0019 & \\
\hline Squared GDP per capita $(\log )$ & -0.093080 & 0.056674 & -1.642317 & 0.0980 & \\
\hline Time linear & -0.018437 & 0.010952 & -1.683454 & 0.0932 & \\
\hline \multicolumn{6}{|c|}{$\begin{array}{l}\text { Dependent variable: logarithm of Environmental protection expenditure by private and public } \\
\text { specialized producers of environmental protection services }\end{array}$} \\
\hline & \multicolumn{5}{|c|}{$\begin{array}{l}\text { Number of observations 323; Sample period 1995-2013; } \\
\text { Number of time periods }(\mathrm{T})=19 \text {; Number of countries }(\mathrm{N})=17\end{array}$} \\
\hline Variable & Coeff. & Std. error & t-statistic & Prob & F-test (prob.) \\
\hline Intercept & -38.62621 & 3.826521 & -10.09434 & 0.0000 & \multirow{4}{*}{$\begin{array}{c}229.4962 \\
(0.0000)\end{array}$} \\
\hline GDP per capita $(\log )$ & 8.274463 & 0.984625 & 8.403665 & 0.0000 & \\
\hline Squared GDP per capita (log) & -0.397063 & 0.062763 & -6.326396 & 0.0000 & \\
\hline Time linear & 0.037683 & 0.012916 & 2.917477 & 0.0038 & \\
\hline
\end{tabular}

Table 2. Random effect GLS regression

\begin{tabular}{|l|c|c|c|c|c|c|}
\hline \multicolumn{5}{|c|}{ Dependent variable: logarithm of Environmental protection expenditure by central government } \\
\hline \multicolumn{5}{|c|}{ Variable } & Number of observations 399; Sample period 1995-2013; \\
Number of time periods (T) =19; Number of countries (N) = 21
\end{tabular}


In order to check if the relationship is also verified at the level of each country, we decided to resort to individual country level analyses in order to investigate the desired relationships starting from the same polynomial model using OLS. The results are briefly presented in Table 3 and Table 4, based on data provided by European Commission (2011) and Eurostat (2015).

Table 3. OLS regression results - Dependent variable: Central Government Environmental Protection Expenditure

\begin{tabular}{|c|c|c|c|c|c|c|c|c|}
\hline \multirow[b]{2}{*}{ Country } & \multicolumn{5}{|c|}{ Coefficient } & \multicolumn{3}{|c|}{ The residual test } \\
\hline & 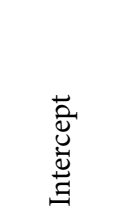 & 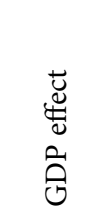 & 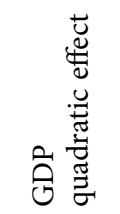 & 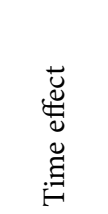 & 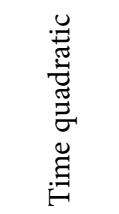 & 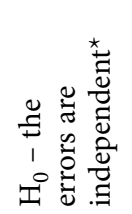 & 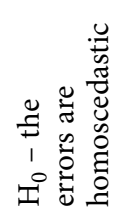 & 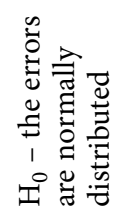 \\
\hline Austria & $\begin{array}{c}-3293.5 \\
(0.00)\end{array}$ & $\begin{array}{l}632.51 \\
(0.00)\end{array}$ & $\begin{array}{l}-30.26 \\
(0.00)\end{array}$ & $\begin{array}{l}-0.76 \\
(0.00)\end{array}$ & $\begin{array}{c}0.02 \\
(0.00)\end{array}$ & 1.402966 & $\begin{array}{c}0.797621 \\
(0.61)\end{array}$ & $\begin{array}{c}2.742719 \\
(0.25)\end{array}$ \\
\hline Belgium & $\begin{array}{c}-985.41 \\
(0.01)\end{array}$ & $\begin{array}{l}191.06 \\
(0.01)\end{array}$ & $\begin{array}{c}-9.2029 \\
(0.01)\end{array}$ & $\begin{array}{c}-0.178 \\
(0.00)\end{array}$ & $\begin{array}{l}0.007 \\
(0.01)\end{array}$ & 2.766596 & $\begin{array}{c}2.968902 \\
(0.06)\end{array}$ & $\begin{array}{c}0.761185 \\
(0.68)\end{array}$ \\
\hline Bulgaria & $\begin{array}{c}-12.66 \\
(0.00)\end{array}$ & $\begin{array}{c}1.89 \\
(0.00)\end{array}$ & - & - & - & 1.338346 & $\begin{array}{c}1.03 \\
(0.37)\end{array}$ & $\begin{array}{c}1.66 \\
(0.43)\end{array}$ \\
\hline Croatia & $\begin{array}{c}-221.67 \\
(0.52)\end{array}$ & $\begin{array}{l}52.62 \\
(0.48)\end{array}$ & $\begin{array}{l}-3.11 \\
(0.44)\end{array}$ & $\begin{array}{c}0.15 \\
(0.81)\end{array}$ & $\begin{array}{l}0.005 \\
(0.82)\end{array}$ & - & - & - \\
\hline Finland & - & $\begin{array}{c}1.73 \\
(0.00)\end{array}$ & $\begin{array}{l}-0.12 \\
(0.00)\end{array}$ & $\begin{array}{c}0.05 \\
(0.00)\end{array}$ & - & 1.808474 & $\begin{array}{c}0.49 \\
(0.77)\end{array}$ & $\begin{array}{c}0.54 \\
(0.76)\end{array}$ \\
\hline France & - & $\begin{array}{c}0.46 \\
(0.00)\end{array}$ & - & $\begin{array}{c}0.03 \\
(0.00)\end{array}$ & $\begin{array}{c}-0.0008 \\
(0.00)\end{array}$ & 1.410494 & $\begin{array}{c}0.56 \\
(0.75)\end{array}$ & $\begin{array}{c}0.61 \\
(0.73)\end{array}$ \\
\hline Germany & $\begin{array}{c}-486.28 \\
(0.00)\end{array}$ & $\begin{array}{l}95.79 \\
(0.00)\end{array}$ & $\begin{array}{l}-4.66 \\
(0.00)\end{array}$ & $\begin{array}{l}-0.12 \\
(0.00)\end{array}$ & $\begin{array}{l}0.005 \\
(0.00)\end{array}$ & 1.893357 & $\begin{array}{c}1.92 \\
(0.16)\end{array}$ & $\begin{array}{c}0.24 \\
(0.88)\end{array}$ \\
\hline Hungary & $\begin{array}{c}-539.46 \\
(0.01)\end{array}$ & $\begin{array}{l}121.36 \\
(0.01)\end{array}$ & $\begin{array}{l}-6.77 \\
(0.01)\end{array}$ & - & - & 1.656050 & $\begin{array}{c}0.77 \\
(0.48)\end{array}$ & $\begin{array}{c}1.89 \\
(0.39)\end{array}$ \\
\hline Italy & $\begin{array}{c}4.44 \\
(0.00)\end{array}$ & - & - & $\begin{array}{c}0.16 \\
(0.00)\end{array}$ & $\begin{array}{c}-0.006 \\
(0.00)\end{array}$ & 0.99435 & $\begin{array}{l}12.97 \\
(0.00)\end{array}$ & $\begin{array}{c}0.02 \\
(0.98)\end{array}$ \\
\hline Latvia & $\begin{array}{c}-344.44 \\
(0.02)\end{array}$ & $\begin{array}{l}75.70 \\
(0.02)\end{array}$ & $\begin{array}{l}-4.10 \\
(0.03)\end{array}$ & - & - & 2.116277 & $\begin{array}{c}4.99 \\
(0.02)\end{array}$ & $\begin{array}{c}0.02 \\
(0.98)\end{array}$ \\
\hline Lithuania & - & $\begin{array}{c}0.13 \\
(0.02)\end{array}$ & - & $\begin{array}{c}0.12 \\
(0.30)\end{array}$ & $\begin{array}{l}0.005 \\
(0.40)\end{array}$ & 0.431235 & $\begin{array}{c}1.56 \\
(0.23)\end{array}$ & $\begin{array}{c}1.70 \\
(0.42)\end{array}$ \\
\hline Luxembourg & $\begin{array}{c}-71.85 \\
(0.03)\end{array}$ & $\begin{array}{l}13.88 \\
(0.03)\end{array}$ & $\begin{array}{l}-0.61 \\
(0.03)\end{array}$ & - & - & 2.329622 & $\begin{array}{c}1.78 \\
(0.20)\end{array}$ & $\begin{array}{c}0.53 \\
(0.76)\end{array}$ \\
\hline Malta & $\begin{array}{c}-633.10 \\
(0.03)\end{array}$ & $\begin{array}{l}135.02 \\
(0.03)\end{array}$ & $\begin{array}{l}-7.15 \\
(0.02)\end{array}$ & $\begin{array}{c}0.11 \\
(0.05)\end{array}$ & - & 3.138798 & $\begin{array}{c}0.56 \\
(0.72)\end{array}$ & $\begin{array}{c}0.12 \\
(0.94)\end{array}$ \\
\hline Poland & $\begin{array}{l}-16.76 \\
(0.00)\end{array}$ & $\begin{array}{c}2.55 \\
(0.00)\end{array}$ & - & $\begin{array}{l}-0.36 \\
(0.00)\end{array}$ & $\begin{array}{c}0.01 \\
(0.00)\end{array}$ & 1.702153 & $\begin{array}{c}6.21 \\
(0.00)\end{array}$ & $\begin{array}{c}1.66 \\
(0.43)\end{array}$ \\
\hline Portugal & $\begin{array}{l}144.64 \\
(0.03)\end{array}$ & $\begin{array}{c}-30.28 \\
(0.03)\end{array}$ & $\begin{array}{c}1.63 \\
(0.02)\end{array}$ & - & - & 1.695185 & $\begin{array}{c}1.77 \\
(0.19)\end{array}$ & $\begin{array}{c}0.39 \\
(0.81)\end{array}$ \\
\hline
\end{tabular}


End of Table 3

\begin{tabular}{|c|c|c|c|c|c|c|c|c|}
\hline \multirow[b]{2}{*}{ Country } & \multicolumn{5}{|c|}{ Coefficient } & \multicolumn{3}{|c|}{ The residual test } \\
\hline & 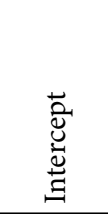 & 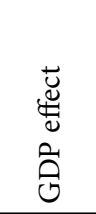 & 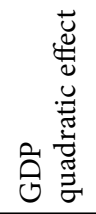 & 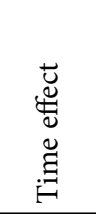 & 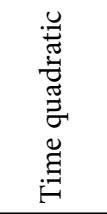 & 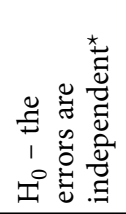 & 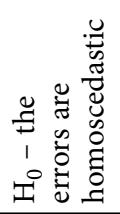 & 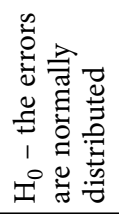 \\
\hline Romania & $\begin{array}{c}-18.34 \\
(0.00)\end{array}$ & $\begin{array}{c}2.85 \\
(0.00)\end{array}$ & - & $\begin{array}{l}-0.38 \\
(0.00)\end{array}$ & $\begin{array}{c}0.01 \\
(0.00)\end{array}$ & 1.419448 & $\begin{array}{c}0.83 \\
(0.59)\end{array}$ & $\begin{array}{l}1.30 \\
(0.52)\end{array}$ \\
\hline Slovakia & $\begin{array}{c}-19.53 \\
(0.15)\end{array}$ & $\begin{array}{c}2.88 \\
(0.12)\end{array}$ & - & $\begin{array}{l}-0.49 \\
(0.21)\end{array}$ & $\begin{array}{c}0.01 \\
(0.17)\end{array}$ & - & - & - \\
\hline Slovenia & $\begin{array}{l}-7.13 \\
(0.97) \\
\end{array}$ & $\begin{array}{c}1.92 \\
(0.96) \\
\end{array}$ & $\begin{array}{l}-0.06 \\
(0.97) \\
\end{array}$ & $\begin{array}{l}-0.01 \\
(0.53) \\
\end{array}$ & - & - & - & - \\
\hline Spain & $\begin{array}{c}-0.006 \\
(0.00)\end{array}$ & - & - & $\begin{array}{c}0.17 \\
(0.00)\end{array}$ & $\begin{array}{l}-0.006 \\
(0.00)\end{array}$ & 0.638820 & $\begin{array}{c}0.52 \\
(0.72)\end{array}$ & $\begin{array}{c}0.47 \\
(0.78)\end{array}$ \\
\hline Sweden & $\begin{array}{c}-19.34 \\
(0.00) \\
\end{array}$ & $\begin{array}{c}2.29 \\
(0.00) \\
\end{array}$ & - & - & - & 0.714203 & $\begin{array}{c}0.19 \\
(0.82) \\
\end{array}$ & $\begin{array}{c}0.64 \\
(0.72) \\
\end{array}$ \\
\hline $\begin{array}{l}\text { United } \\
\text { Kingdom }\end{array}$ & - & $\begin{array}{c}0.73 \\
(0.22)\end{array}$ & $\begin{array}{l}-0.02 \\
(0.65)\end{array}$ & $\begin{array}{c}0.05 \\
(0.48)\end{array}$ & $\begin{array}{c}0.0003 \\
(0.91)\end{array}$ & - & - & - \\
\hline
\end{tabular}

Note: () the probabilities. ${ }^{\star}$ Durbin-Watson Statistic: 1 Per Cent Significance Points of dL and dU for $\mathrm{T}=19$, and: $\mathrm{k}=1 \mathrm{~d}_{\mathrm{L}}=0.92$ and $\mathrm{d}_{\mathrm{U}}=1.13 ; \mathrm{k}=2 \mathrm{~d}_{\mathrm{L}}=0.83$ and $\mathrm{d}_{\mathrm{U}}=1.26 ; \mathrm{k}=3 \mathrm{~d}_{\mathrm{L}}=0.74$ and $\mathrm{d}_{\mathrm{U}}=1.41$; $\mathrm{k}=4 \mathrm{~d}_{\mathrm{L}}=0.65$ and $\mathrm{d}_{\mathrm{U}}=1.58$.

As noticed in Table 3, for almost half of the investigated countries, no valid model was found. The relationship between GDP and Government Environmental Expenditure is linear, positive and significant for 16 countries. In the case of Austria, Belgium, Finland, Germany, Hungary, Latvia, Luxembourg and Malta, in addition to the linear and positive GDP effect, there is also a significant negative, quadratic GDP effect. Therefore, we can conclude that Central Government Environmental Protection Expenditure has the tendency to initially increase and then decrease over time (concave curvature), while under the effect of GDP growth the Central Government Environmental Protection Expenditure increased.

For Austria, Belgium, Germany and Romania, in addition to the effects of GDP, quadratic GDP effect and time (linear), we can also notice a quadratic effect of time, with a positive coefficient, leading to the conclusion that, in time, Central Government Environmental Protection Expenditure tends to change according to a convex path. By itself, Central Government Environmental Protection Expenditure in these countries would decrease following a convex curve, characterized by smaller increments every year. However, due to GDP growth effects, this negative time-dependence is counterbalanced and even outweighed, leading to a net growth of the expenditure.

In the next category we found two countries, i.e. Italy and Spain, which show an increasing trend in time, with a negative quadratic coefficient suggesting a concave curvature. For both countries, GDP does not seem to significantly influence governmental environmental expenditure, but only by time. For these countries, it tends to increase in time, however at a smaller rate each year, which could result either in stagnation or be suggestive of a cyclic evolution. In order to correctly determine the trend, a longer time series would be required. 
Table 4. OLS regression results - Dependent variable: Environmental protection expenditure - Specialized providers (public and private)

\begin{tabular}{|c|c|c|c|c|c|c|c|c|}
\hline \multirow[b]{2}{*}{ Country } & \multicolumn{5}{|c|}{ Coefficient } & \multicolumn{3}{|c|}{ The residual test } \\
\hline & 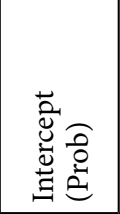 & 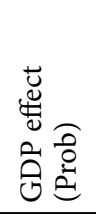 & 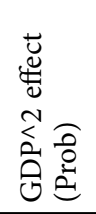 & 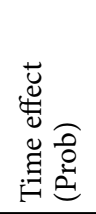 & 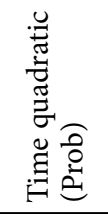 & 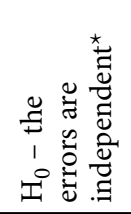 & 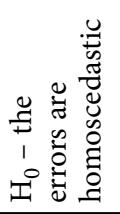 & 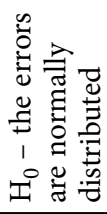 \\
\hline Austria & $\begin{array}{c}6.43 \\
(0.00)\end{array}$ & - & - & $\begin{array}{l}-0.02 \\
(0.09)\end{array}$ & $\begin{array}{l}0.003 \\
(0.00)\end{array}$ & 1.736537 & $\begin{array}{c}0.82 \\
(0.53)\end{array}$ & $\begin{array}{c}0.74 \\
(0.68)\end{array}$ \\
\hline Belgium & $\begin{array}{c}4.71 \\
(0.00)\end{array}$ & - & - & $\begin{array}{c}0.10 \\
(0.00)\end{array}$ & $\begin{array}{c}-0.002 \\
(0.00)\end{array}$ & 1.923443 & $\begin{array}{c}1.02 \\
(0.42)\end{array}$ & $\begin{array}{c}0.56 \\
(0.75)\end{array}$ \\
\hline Bulgaria & $\begin{array}{c}-23.79 \\
(0.00)\end{array}$ & $\begin{array}{c}3.15 \\
(0.00) \\
\end{array}$ & - & - & - & 1.019925 & $\begin{array}{c}1.82 \\
(0.19) \\
\end{array}$ & $\begin{array}{c}0.01 \\
(0.99)\end{array}$ \\
\hline Croatia & - & - & - & $\begin{array}{c}0.37 \\
(0.00)\end{array}$ & $\begin{array}{l}-0.01 \\
(0.00)\end{array}$ & 0.954102 & $\begin{array}{c}1.45 \\
(0.26)\end{array}$ & $\begin{array}{c}0.10 \\
(0.94)\end{array}$ \\
\hline Finland & $\begin{array}{c}-278.41 \\
(0.00)\end{array}$ & $\begin{array}{l}53.59 \\
(0.00)\end{array}$ & $\begin{array}{l}-2.54 \\
(0.00)\end{array}$ & - & - & 1.403789 & $\begin{array}{c}0.18 \\
(0.83)\end{array}$ & $\begin{array}{c}2.61 \\
(0.27)\end{array}$ \\
\hline France & $\begin{array}{c}-156.46 \\
(0.00)\end{array}$ & $\begin{array}{l}30.39 \\
(0.00)\end{array}$ & $\begin{array}{l}-1.41 \\
(0.00)\end{array}$ & - & - & 1.331167 & $\begin{array}{c}0.68 \\
(0.52)\end{array}$ & $\begin{array}{c}1.01 \\
(0.60)\end{array}$ \\
\hline Germany & - & $\begin{array}{c}0.50 \\
(0.00)\end{array}$ & & $\begin{array}{c}0.05 \\
(0.00)\end{array}$ & $\begin{array}{c}-0.002 \\
(0.00)\end{array}$ & 1.298674 & $\begin{array}{c}1.16 \\
(0.38)\end{array}$ & $\begin{array}{c}1.06 \\
(0.58)\end{array}$ \\
\hline Hungary & $\begin{array}{c}-11.55 \\
(0.00)\end{array}$ & $\begin{array}{c}1.78 \\
(0.00)\end{array}$ & - & $\begin{array}{l}-0.04 \\
(0.00)\end{array}$ & - & 0.950913 & $\begin{array}{c}1.44 \\
(0.30)\end{array}$ & $\begin{array}{c}0.22 \\
(0.89)\end{array}$ \\
\hline Italy & $\begin{array}{c}-22.77 \\
(0.00) \\
\end{array}$ & $\begin{array}{c}2.80 \\
(0.00)\end{array}$ & - & - & - & 0.648663 & $\begin{array}{l}22.84 \\
(0.00)\end{array}$ & $\begin{array}{c}1.99 \\
(0.36)\end{array}$ \\
\hline Latvia & $\begin{array}{l}-6.81 \\
(0.00)\end{array}$ & $\begin{array}{c}1.15 \\
(0.00)\end{array}$ & - & - & - & 2.156451 & $\begin{array}{c}0.33 \\
(0.72)\end{array}$ & $\begin{array}{c}2.50 \\
(0.28)\end{array}$ \\
\hline Lithuania & $\begin{array}{l}-4.30 \\
(0.00) \\
\end{array}$ & $\begin{array}{c}0.91 \\
(0.00) \\
\end{array}$ & - & - & - & 1.341634 & $\begin{array}{c}0.17 \\
(0.84) \\
\end{array}$ & $\begin{array}{c}0.73 \\
(0.69) \\
\end{array}$ \\
\hline Luxembourg & - & $\begin{array}{c}0.53 \\
(0.00) \\
\end{array}$ & - & - & - & 1.692581 & $\begin{array}{c}2.88 \\
(0.10) \\
\end{array}$ & $\begin{array}{c}3.53 \\
(0.17) \\
\end{array}$ \\
\hline $\begin{array}{l}\text { Czech } \\
\text { Republic }\end{array}$ & $\begin{array}{l}-3.42 \\
(0.01)\end{array}$ & $\begin{array}{c}0.82 \\
(0.00)\end{array}$ & - & - & - & 1.495288 & $\begin{array}{c}1.74 \\
(0.20)\end{array}$ & $\begin{array}{l}22.77 \\
(0.00)\end{array}$ \\
\hline Romania & $\begin{array}{c}-117.34 \\
(0.00)\end{array}$ & $\begin{array}{l}27.49 \\
(0.00)\end{array}$ & $\begin{array}{l}-1.54 \\
(0.00)\end{array}$ & - & - & 2.241741 & $\begin{array}{c}2.40 \\
(0.10)\end{array}$ & $\begin{array}{c}1.16 \\
(0.55)\end{array}$ \\
\hline Slovakia & $\begin{array}{c}-18.35 \\
(0.00)\end{array}$ & $\begin{array}{c}2.26 \\
(0.00)\end{array}$ & - & - & - & 1.757112 & $\begin{array}{c}1.07 \\
(0.36)\end{array}$ & $\begin{array}{l}52.99 \\
(0.00)\end{array}$ \\
\hline Slovenia & $\begin{array}{c}-504.34 \\
(0.00) \\
\end{array}$ & $\begin{array}{c}105.04 \\
(0.00)\end{array}$ & $\begin{array}{l}-5.42 \\
(0.00) \\
\end{array}$ & - & - & 2.583268 & $\begin{array}{c}0.86 \\
(0.44) \\
\end{array}$ & $\begin{array}{c}0.83 \\
(0.65) \\
\end{array}$ \\
\hline Spain & - & $\begin{array}{c}0.51 \\
(0.00)\end{array}$ & - & $\begin{array}{c}0.02 \\
-0.00)\end{array}$ & - & 1.306666 & $\begin{array}{c}0.37 \\
(0.77)\end{array}$ & $\begin{array}{c}0.83 \\
(0.65)\end{array}$ \\
\hline
\end{tabular}

Note: () the probabilities. ${ }^{\star}$ Durbin-Watson Statistic: 1 Per Cent Significance Points of dL and dU for $\mathrm{T}=19$, and: $\mathrm{k}=1 \mathrm{~d}_{\mathrm{L}}=0.92$ and $\mathrm{d}_{\mathrm{U}}=1.13 ; \mathrm{k}=2 \mathrm{~d}_{\mathrm{L}}=0.83$ and $\mathrm{d}_{\mathrm{U}}=1.26 ; \mathrm{k}=3 \mathrm{~d}_{\mathrm{L}}=0.74$ and $\mathrm{d}_{\mathrm{U}}=1.41$; $\mathrm{k}=4 \mathrm{~d}_{\mathrm{L}}=0.65$ and $\mathrm{d}_{\mathrm{U}}=1.58$. 
Regarding the expenditure of specialized public and private providers, for only four countries no valid model was found. The Czech Republic displays a positive and significant relation between GDP and expenditure of specialized public and private providers in the current analysis, but not enough data was available to compute the indicators for the previous analysis. Compared to the previous analysis for Malta, Poland, Portugal, Sweden and United Kingdom, not enough data was available to compute the indicators of the expenditure of specialized public and private.

The largest group is that of countries which are influenced only by GDP, which includes Germany, Latvia, Lithuania, Luxemburg, the Czech Republic, Slovakia and Spain. They all display a positive relation, and therefore in the case of these countries we can conclude that GDP is a significant and strong predictor of Environmental protection expenditure by specialized providers (public and private), in a linear and time independent manner.

Another group comprises Finland, France, Romania and Slovenia, which display a linear and quadratic GDP effect, however in opposite directions. In this case we can conclude that the expenditure of specialized public and private has the tendency to initially increase and then decrease over time (concave curvature), while under the effect of GDP growth the Environmental protection expenditure by specialized providers (public and private) increased.

The next group countries comprise Austria, Belgium, and Germany, which display a linear and quadratic time effect, however in opposite directions. In the case of Austria, the time (linear) has a negative effect on the expenditure which shows that, in time, the Expenditure tends to decrease, and a positive quadratic coefficient, which suggest a convex curvature in time. Consequently, we draw the conclusion that in Austria, Environmental protection expenditure by public and private, specialized providers tends to decrease with time, but with smaller yearly differences. In the case of Belgium and Germany, there is a positive time effect with a negative quadratic effect, which indicates that Environmental protection expenditure by specialized providers (public and private) tends to increase year by year, but with decreasing increments.

\section{Conclusions}

In this paper we have analyzed the relationship between the environmental expenditure and the GDP for the European Union countries, by using a panel data analysis and a regression equation for an individual analysis on the selected EU countries.

The empirical investigation for the 1995-2013 period, based on fixed effect and random effect estimations, suggests a positive GDP effect and a negative quadratic GDP effect in relation to the investment in environmental protection.

These outcomes are consistent with previous studies examining the relationship between environment and GDP growth in European countries, such as Atici (2009), Acaravci and Ozturk (2010), Lapinskienè, Tvaronavičienè, and Vaitkus (2014), Al-Mulali et al. (2015), Marques et al. (2017). Thus, the relatively high GDP of some EU countries leads to environmental improvement in those countries, both for government environmental protection and specialized providers, public and private environmental protection. Further individual country analysis shows that the EKC is supported for governmental environmental investment in 
8 countries, while in the case of the investments of specialized providers, the Kuznets theory holds only for 4 countries. The relationship between GDP and the investment in environmental protection is significant and positive for more than a half of the investigated countries. In our analysis, we only found a negative relation between GDP and government environmental protection in the case of Portugal. Examining this situation, we can state that, if the GDP growth in this country (and in other countries with the same effects) is sustainable, it has no significant environmental impact, which is not necessarily a negative fact. However, if GDP growth is associated with an increase in pollution and in the consumption of non-renewable energy, the deficiency of significant investment in environmental protection will result, in the long run, in severe environmental damages. Therefore, as resulted from the research findings, it would be beneficial for the economy to increase the number of investmeprojects and to promote the role of renewable energy in the low-carbon greenhouse gas sectors and reduce these emissions, especially in the transport and energy sectors, and to promote new research into renewable energy technologies. Were Kuznets' theory be valid in this case, the problem would solve itself due to the positive impact of economic growth on the environment, represented by the second section of the curve. However, since the coefficient of the quadratic GDP is positive, we can conclude that the theory is not supported and some effective policies should be developed to increase the involvement in environmental protection. Additionally, these countries should concentrate more on structural changes that lead to an environmentally friendly GDP growth. Otherwise, negative and persistent consequences would arise. It can be noticed that, as economies grow over time, the emissions of many pollutants initially rise and then decrease, while in the absence of technological breakthroughs and changes in the structure of production, economic growth would lead to higher pollution levels. Since the objective of the environmental policy is not to slow down economic growth or to reduce the production of certain sectors, it is important that it allows for a wide range of innovative technological solutions for environmental issues. In addition, as revealed by our research results, the focus on renewable energy brings not only environmental benefits but also many benefits with economic and social impact. One important benefit for the countries under consideration would be to reduce the dependence on energy imports, lower greenhouse gas emissions, increase employment in the energy sectors and improve innovation in non-polluting industries. These policies could help countries to increase their energy efficiency in general, which in turn reduces their environmental degradation due to higher economic activity.

Additionally to the previous studies, our paper contributes to enriching the existing EKC literature by introducing and investigating two new variables, namely the environmental protection expenditure by central government, and the environmental protection expenditure by private and public specialized producers of environmental protection services. To our best knowledge, there is no previous study focused on these variables in the same framework for the countries selected in this paper.

The main limitations of our study are related to the focus on a limited number of variables, which we have considered as suggestive and therefore selected for investigating the relations between economic growth and environmental expenditure, and to the relatively small available data sets and, therefore, the limited econometric methods that can be used in this case. 
Future research should focus on the renewable energy systems and new technologies able to significantly reduce the environmental impact of human activities. Another direction of research could be the investigation of the environmental and economic impact of the new pollutants, whose amounts and effects are certainly related to the technological improvements. Moreover, searching for adequate environmental means to address the new challenges level would be of high interest both for the theoretical advance of knowledge and for improving the practice and policies which should be carried at national and regional level.

\section{Funding}

This research received no external funding.

\section{Author contributions}

The paper is a result of a collaborative work.

\section{Disclosure statement}

The authors declare there are no competing financial, professional, or personal interests from other parties.

\section{References}

Acaravci, A., \& Akalin, G. (2017). Environment-economic growth nexus: a comparative analysis of developed and developing countries. International Journal of Energy Economics and Policy, 7(5), 34-43.

Acaravci, A., \& Ozturk, I. (2010). On the relationship between energy consumption, $\mathrm{CO}_{2}$ emissions and economic growth in Europe. Energy, 35(12), 5412-5420.

https://doi.org/10.1016/j.energy.2010.07.009

Al-Mulali, U., Ozturk, I., \& Lean, H. H. (2015). The influence of economic growth, urbanization, trade openness, financial development, and renewable energy on pollution in Europe. Natural Hazards, 79(1), 621-644. https://doi.org/10.1007/s11069-015-1865-9

Al-Mulali, U., Ozturk, I., \& Solarin, S. A. (2016). Investigating the environmental Kuznets curve hypothesis in seven regions: The role of renewable energy. Ecological Indicators, 67, 267-282. https://doi.org/10.1016/j.ecolind.2016.02.059

Alpay, E., Buccola, S., \& Kerkvliet, J. (2002). Productivity growth and environmental regulation in Mexican and US food manufacturing. American Journal of Agricultural Economics, 84(4), 887-901. https://doi.org/10.1111/1467-8276.00041

Anastacio, J. A. R. (2017). Economic growth, $\mathrm{CO}_{2}$ emissions and electric consumption: Is there an environmental Kuznets curve? An empirical study for North America countries. International Journal of Energy Economics and Policy, 7(2), 65-71.

Andreoni, J., \& Levinson, A. (2001). The simple analytics of the environmental Kuznets curve. Journal of Public Economics, 80(2), 269-286. https://doi.org/10.1016/S0047-2727(00)00110-9

Atici, C. (2009). Carbon emissions in central and eastern Europe: environmental Kuznets curve and implications for sustainable development. Sustainable Development, 17(3), 155-160.

https://doi.org/10.1002/sd.372 
Bac, D. P. (2008). A history of the concept of sustainable development: Literature review. The Annals of the University of Oradea. Economic Sciences Series, 17(2), 576-580.

Badulescu, D., Bungau, C., \& Badulescu, A. (2015). Sustainable development through sustainable businesses. An empirical research among master students. Journal of Environmental Protection and Ecology, 16(3), 1101-1108.

Badulescu, D., Badulescu, A., Sipos-Gug, S., \& Rangone, A. (2016). Different or alike? Investigating the impact of GDP on environmental protection expenditure in selected European States. Global \& Local Economic Review, 20(1), 55-75.

Becker, R. (2011). Local environmental regulation and plant-level productivity. Ecological Economics, 70, 2513-2522. https://doi.org/10.1016/j.ecolecon.2011.08.019

Beckerman, W. (1992). Economic growth and the environment: whose growth? Whose environment? World Development, 20, 481-496. https://doi.org/10.1016/0305-750X(92)90038-W

Cole, M. (2003). Development, trade, and the environment: How robust is the environmental Kuznets curve? Environment and Development Economics, 8, 557-580. https://doi.org/10.1017/S1355770X0300305

Cole, M. (2004). Trade, the pollution haven hypothesis and the environmental Kuznets curve: examining the linkages. Ecological Economics, 48(1), 71-81. https://doi.org/10.1016/j.ecolecon.2003.09.007

Cropper, M., \& Griffiths, C. (1994). The interaction of population growth and environmental quality. American Economic Review, 84(2), 250-254.

De Santis, R., \& Lasinio, C. (2015). Environmental policies, innovation and productivity in the EU (LEQS paper No. 100/2015). The London School of Economics and Political Science (LSE). https://doi.org/10.2139/ssrn.2696266

Dechezleprêtre, A., \& Sato, M. (2014). The impacts of environmental regulations on competitiveness: policy brief. Grantham Research Institute on Climate Change and the Environment, The London School of Economics.

Dewan, E., \& Hussein, S. (2001). Determinants of economic growth (panel data approach) (Working paper No. 01/04). Retrieved from http://www.rbf.gov.f//docs/wp2001-04.pdf

Dijkgraaf, E., \& Vollebergh, H. (2005). A test for parameter homogeneity in $\mathrm{CO}_{2}$ panel EKC estimations. Environmental and Resource Economics, 32(2), 229-239.

https://doi.org/10.1007/s10640-005-2776-0

Dinda, S. (2005). A theoretical basis for the environmental Kuznets curve. Ecological Economics, 53(3), 403-413. https://doi.org/10.1016/j.ecolecon.2004.10.007

Dutt, K. (2009). Governance, institutions and the environment-income relationship: a cross-country study. Environment, Development and Sustainability, 11(4), 705-723. https://doi.org/10.1007/s10668-007-9138-8

Ekins, P. (1993). 'Limits to growth' and 'sustainable development': grappling with ecological realities. Ecological Economics, 8(3), 269-288. https://doi.org/10.1016/0921-8009(93)90062-B

Ekins, P. (1997). The Kuznets curve for the environment and economic growth: examining the evidence. Environment and Planning, 29(5), 805-830. https://doi.org/10.1068/a290805

European Commission. (2011). Environmental protection expenditure in Europe - Data 1995-2009. Luxembourg: Publications Office of the European Union.

Eurostat. (2008). NACE Rev. 2. Statistical classification of economic activities in the European Community. Luxembourg: Office for Official Publications of the European Communities.

Eurostat. (2017). Environmental protection expenditure accounts Handbook 2017 edition. Luxembourg: Publications Office of the European Union.

Everett, T., Ishwaran, M., Ansaloni, G. P., \& Rubin, A. (2010). Economic growth and the environment. Department for Environment Food and Rural Affairs. 
Frankel, J. (2003, November). The environment and globalization (Working paper No. 10090). https://doi.org/10.3386/w10090

Galeotti, M., \& Lanza, A. (1999). Richer and cleaner? A study on carbon dioxide emissions in developing countries. Energy Policy, 27(10), 565-573. https://doi.org/10.1016/S0301-4215(99)00047-6

Galeotti, M., Lanza, A., \& Pauli, F. (2006). Reassessing the environmental Kuznets curve for $\mathrm{CO}_{2}$ emissions: A robustness exercise. Ecological Economics, 57(1), 152-163. https://doi.org/10.1016/j.ecolecon.2005.03.031

Gray, W. (1987). The cost of regulation: OSHA, EPA and the productivity slowdown. The American Economic Review, 77(5), 998-1006.

Greenstone, M., List, J., \& Syverson, C. (2012). The effects of environmental regulation on the competitiveness of US manufacturing. (Working paper No. 18392). Cambridge, Massachusetts. https://doi.org/10.3386/w18392

Grossman, G., \& Krueger, A. (1995). Economic growth and the environment. The Quarterly Journal of Economics, 110(2), 353-377. https://doi.org/10.2307/2118443

Grossman, G., \& Krueger, A. (1991). Environmental impacts of a North American free trade agreement (Working paper No. 3914). National Bureau of Economic Research. https://doi.org/10.3386/w3914

Hausman, J. (1978). Specification tests in econometrics. Econometrica, 46, 1251-1271. https://doi.org/10.2307/1913827

Hettige, H., Lucas, R., \& Wheeler, D. (1992). The toxic intensity of industrial production: global patterns, trends and trade policy. American Economic Review, 82, 478-481.

Jebli, M. B., Youssef, S. B., \& Ozturk, I. (2016). Testing environmental Kuznets curve hypothesis: The role of renewable and non-renewable energy consumption and trade in OECD countries. Ecological Indicators, 60, 824-831. https://doi.org/10.1016/j.ecolind.2015.08.031

John, A., \& Pecchenino, R. (1994). An overlapping generations model of growth and the environment. The Economic Journal, 104(427), 1393-1410. https://doi.org/10.2307/2235455

Kearsley, A., \& Riddel, M. (2010). A further inquiry into the Pollution Haven Hypothesis and the Environmental Kuznets Curve. Ecological Economics, 69(4), 905-919.

https://doi.org/10.1016/j.ecolecon.2009.11.014

Keho, Y. (2017). Revisiting the income, energy consumption and carbon emissions nexus: New evidence from quantile regression for different country groups. International Journal of Energy Economics and Policy, 7(3), 356-363.

Koźluk, T., \& Zipperer, V. (2015). Environmental policies and productivity growth - a critical review of empirical findings. OECD Journal: Economic Studies, 2014, 155-185. https://doi.org/10.1787/eco_studies-2014-5jz2drqml75j

Kuznets, S. (1955). Economic growth and income inequality. American Economic Review, XLV(1), 1-28.

Lapinskienė, G., Tvaronavičienė, M., \& Vaitkus, P. (2014). Greenhouse gases emissions and economic growth - evidence substantiating the presence of environmental Kuznets curve in the EU. Technological and Economic Development of Economy, 20(1), 65-78. https://doi.org/10.3846/20294913.2014.881434

Lecomber, R. (1975). Economic growth versus the environment. London: Macmillan. https://doi.org/10.1007/978-1-349-02074-4

Levinson, A., \& Taylor, M. (2004). Unmasking the pollution haven effect (Working paper No. 10629). https://doi.org/10.3386/w10629

Lieb, C. (2002). The Environmental Kuznets Curve and satiation: a simple static model. Environment and Development Economics, 7(3), 429-448. https://doi.org/10.1017/S1355770X02000268

Lopez, R. (1994). The environment as a factor of production: the effects of economic growth and trade liberalization. Journal of Environmental Economics and Management, 27(2), 163-184.

https://doi.org/10.1006/jeem.1994.1032 
Magnani, E. (2000). The Environmental Kuznets Curve, environmental protection policy and income distribution. Ecological Economics, 32(2), 431-443. https://doi.org/10.1016/S0921-8009(99)00115-9

Managi, S., Opaluch, J., Jin, D., \& Grigalunas, T. (2005). Environmental regulations and technological change in the offshore oil and gas industry. Land Economics, 81(2), 303-319.

https://doi.org/10.3368/le.81.2.303

Marques, L. M., Fuinhas, J. A., \& Marques, A. C. (2017). On the dynamics of energy-growth nexus: evidence from a world divided into four regions. International Journal of Energy Economics and Policy, 7(3), 208-215.

Meadows, D., Meadows, D., Randers, J., \& Behrens, W. (1972). The limits to growth: a report for the club of Rome's project on the predicament of mankind. New York: Universe Books. https://doi.org/10.1349/ddlp.1

Mensah, J. T. (2014). Carbon emissions, energy consumption and output: A threshold analysis on the causal dynamics in emerging African economies. Energy Policy, 70(14), 172-182. https://doi.org/10.1016/j.enpol.2014.03.038

Mishenin, Y., Koblianska, I., Medvid, V., \& Maistrenko, Y. (2018). Sustainable regional development policy formation: role of industrial ecology and logistics. Entrepreneurship and Sustainability Issues, 6(1), 329-341. https://doi.org/10.9770/jesi.2018.6.1(20)

Panayotou, T. (2000). Economic growth and the environment (CID Working Paper No. 56). Center for International Development at Harvard University.

Pearce, D., \& Palmer, C. (2001). Public and private spending for environmental protection: a crosscountry policy analysis. Fiscal Studies, 22(4), 403-456. https://doi.org/10.1111/j.1475-5890.2001.tb00048.x

Pesaran, M., \& Shin, Y. (1999). An autoregressive distributed lag modelling approach to cointegration analysis (chapter 11). In S. Strom (Ed.), Econometrics and economic theory in 20th century: the Ragnar Frisch centennial symposium (pp. 371-413). Cambridge: Cambridge University Press. https://doi.org/10.1017/CBO9781139052221.011

Pesaran, M., Shin, Y., \& Smith, R. (2001). Bounds testing approaches to the analysis of level relationships. Journal of Applied Econometrics, 16(3), 289-326. https://doi.org/10.1002/jae.616

Peters, G., Minx, J., Weber, C., \& Edenhofer, O. (2011). Growth in emission transfers via international trade from 1990 to 2008. Proceedings of the National Academy of Sciences of the United States of America (PNAS), 108(21), 8903-8908, https://doi.org/10.1073/pnas.1006388108

Rafindadi, A. A., \& Ozturk, I. (2017). Impacts of renewable energy consumption on the German economic growth: Evidence from combined cointegration test. Renewable and Sustainable Energy Reviews, 75, 1130-1141. https://doi.org/10.1016/j.rser.2016.11.093

Rauf, A., Liu, X., Amin, W., Ozturk, I., Rehman, O. U., \& Hafeez, M. (2018). Testing EKC hypothesis with energy and sustainable development challenges: A fresh evidence from Belt and Road Initiative economies. Environmental Science and Pollution Research, 25(32), 32066-32080. https://doi.org/10.1007/s11356-018-3052-5

Rogalev, A., Komarov, I., Kindra, V., \& Zlyvko, O. (2018). Entrepreneurial assessment of sustainable development technologies for power energy sector. Entrepreneurship and Sustainability Issues, 6(1), 429-445. https://doi.org/10.9770/jesi.2018.6.1(26)

Selden, T., \& Song, D. (1994). Environmental quality and development: is there a Kuznets curve for air pollution emissions? Journal of Environmental Economics and Management, 27, 147-162. https://doi.org/10.1006/jeem.1994.1031

Shahbaz, M., Dube, S., Ozturk, I., \& Jalil, A. (2015). Testing the environmental Kuznets curve hypothesis in Portugal. International Journal of Energy Economics and Policy, 5(2), 475-481.

Smith, J., \& Sims, W. (1985). The impact of pollution charges on productivity growth in Canadian brewing. The RAND Journal of Economics, 16(3), 410-423. https://doi.org/10.2307/2555567 
Stjepanović, S., Tomić, D., \& Škare, M. (2017). A new approach to measuring green GDP: a crosscountry analysis. Entrepreneurship and Sustainability Issues, 4(4), 574-590. https://doi.org/10.9770/jesi.2017.4.4(13)

Stern, D., Common, M., \& Barbier, E. (1996). Economic growth and environmental degradation: The environmental Kuznets curve and sustainable development. World Development, 24(7), 1151-1160. https://doi.org/10.1016/0305-750X(96)00032-0

Stern, D., (2004). The rise and fall of the environmental Kuznets curve. World Development, 32(8), 1419-1439. https://doi.org/10.1016/j.worlddev.2004.03.004

Suri, V., \& Chapman, D. (1998). Economic growth, trade and energy: implications for the environmental Kuznets curve. Ecological Economics, 25(2), 195-208. https://doi.org/10.1016/S0921-8009(97)00180-8

Tahvonen, O., \& Kuuluvainen, J. (1993). Economic growth, pollution, and renewable resources. Journal of Environmental Economics and Management, 24(2), 101-118. https://doi.org/10.1006/jeem.1993.1007

Uchiyama, K. (2016). Environmental Kuznets Curve Hypothesis. In K. Uchiyama (Ed.), Environmental Kuznets Curve Hypothesis and Carbon Dioxide Emissions (pp. 11-29). Tokyo, Japan: Springer. https://doi.org/10.1007/978-4-431-55921-4

Vegera, S., Malei, A., Sapeha, I., \& Sushko, V. (2018a). Information support of the circular economy: the objects of accounting at recycling technological cycle stages of industrial waste. Entrepreneurship and Sustainability Issues, 6(1), 190-210. https://doi.org/10.9770/jesi.2018.6.1(13)

Vegera, S., Malei, A., \& Trubovich, R. (2018b). Accounting development of natural resources in organizations carrying out the disposal of municipal waste and biogas extraction in the context of the "green" economy. Entrepreneurship and Sustainability Issues, 6(1), 211-225. https://doi.org/10.9770/jesi.2018.6.1(14)

World Trade Organization. (1999). Special studies 4. Trade and environment. Geneva: WTO Publications.

Wu, Y., \& Wang, B. (2008). Environmental regulation and total factor productivity growth: an empirical study of the APEC economies. Economic Research Journal, 5, 19-33.

Yang, C., Tseng, Y., \& Chen, C. (2012). Environmental regulations, induced R\&D, and productivity: evidence from Taiwan's manufacturing industries. Resource and Energy Economics, 34, 514-532. https://doi.org/10.1016/j.reseneeco.2012.05.001

Yörük, B., \& Zaim, O. (2005). Productivity growth in OECD countries: a comparison with Malmquist indices. Journal of Comparative Economics, 33(2), 401-420. https://doi.org/10.1016/j.jce.2005.03.011 